\title{
WATER QUALITY IN THE BRAZILIAN SEMI-ARID: BIOPROSPECTING OF CHROMOBACTERIUM VIOLACEUM FOR METAL BIOREMEDIATION
}

\author{
Feliphe lacerda Souza de Alencar $^{1 *}$, Ermeton Duarte Do Nascimento ${ }^{1}$, Gilberto Corso ${ }^{2}$, \\ Magnólia Fernandes Florêncio de Araújo ${ }^{1}$
}

\author{
1 Universidade Federal do Rio Grande do Norte, Departamento de Microbiologia e Parasitologia \\ 2 Universidade Federal do Rio Grande do Norte, Departamento de Biofísica \\ * Autor para correspondência: feliphe.lacerda7@hotmail.com
}

Recebido em 17 de agosto de 2018. Aceito em 18 de dezembro de 2019. Publicado em 30 de dezembro de 2019.

\begin{abstract}
The environmental impacts from metal accumulation cause disorders that often hinder recovery and control of these locations. This study evaluated the physical-chemical and microbiological parameters of water quality in a reservoir located in semiarid region of Rio Grande do Norte, Brazil (near a mining iron industry), as well as bioprospecting Chromobacterium violaceum (wild strains and ATCC 12472) for metal bioremediation, through investigation, comparison and inferential analysis of their phenotypic resistance patterns to iron, manganese and zinc metals in different exposure times, concentrations and interactions. The physicochemical water analysis revealed acceptable parameters, except the $\mathrm{pH}$ of the fifth site. In this site it was isolated C. violaceum. Both C. violaceum strains were resistant to metals tested in different exposure intervals, concentrations and interactions $(\mathrm{p}<10-5)$. However, it was observed that the wild strain showed a more efficient acute phase response when compared to the standard it, especially for metal concentrations between $80-48$ (10-1 $\mathrm{g} / \mathrm{l}$. Zinc when interacting individually or jointly with metals iron and manganese increased resistance patterns in wild strain, whereas the reverse process was verified for ATCC strains. The bioprospecting tests demonstrated the importance of C. violaceum as a tool for metals bioremediation and highlight the importance of environmental monitoring and application of bioremediation in areas impacted by the aforementioned problem.
\end{abstract}

KEYWORDs: bacterial resistance; bioprospecting; Chromobacterium violaceum and metals.

QUALIDADE HÍDRICA NO SEMIÁRIDO BRASILEIRO: BIOPROSPECÇÃo DA CHROMOBACTERIUM VIOLACEUM PARA A BIORREMEDIAÇÃo DE METAIS

Resumo - Os impactos ambientais provenientes da acumulação de metal causam distúrbios que muitas vezes impedem a recuperação e controle desses locais. Este estudo avaliou os parâmetros físico-químicos e microbiológicos da qualidade da água de um reservatório localizado no semiárido do Rio Grande do Norte, Brasil (próximo a uma mineradora de ferro), bem como a bioprospecção da Chromobacterium violaceum (cepas selvagem e ATCC 12472) para a biorremediação de metais, através da investigação, comparação e análises inferenciais de seus padrões de resistência fenotípica ao ferro, manganês e zinco em diferentes tempos de exposição, concentrações e interações. A análise físico-química da água revelou parâmetros aceitáveis, exceto para o $\mathrm{pH}$ do quinto local de coleta. Neste local, foi isolada a C. violaceum. Ambas as cepas de C. violaceum foram resistentes aos metais testados em diferentes intervalos de exposição, concentrações e interações $\left(p<10^{-5}\right)$. No entanto, foi observado que a cepa selvagem mostrou uma resposta de fase aguda mais eficiente quando comparada a padrão, sobretudo para as concentrações entre $80-48\left(10^{-1} \mathrm{~g} / \mathrm{l}\right)$. O zinco ao interagir individualmente ou em conjunto com o ferro e o manganês elevou os padrões de resistência na cepa selvagem, enquanto que o processo inverso foi verificado para a cepa ATCC 12472. Os testes de bioprospecção demonstraram a importância da C. violaceum como ferramenta para a biorremediação de metais 
e destacam a importância do monitoramento ambiental e aplicação da biorremediação em áreas afetadas pela problemática exposta.

Palavras-chave: bioprospecção, Chromobacterium violaceum, metais e resistência bacteriana.

\section{Calidad hídrica en el semiárido brasileño: Bioprospección de la Chromobacterium violaceum para la BIORREMEDIACIÓN DE METALES}

Resumen - Los impactos ambientales provenientes de la acumulación de metal causan disturbios que a menudo impiden la recuperación y control de esos lugares. Este estudio evaluó los parámetros físico-químicos y microbiológicos de la calidad del agua de un depósito localizado en el semiárido de Rio Grande do Norte, Brasil (cerca de una minería de hierro), así como la bioprospección de la Chromobacterium violaceum (cepas salvajes ATCC 12472) para la biorremediación de metales, a través de la investigación, comparación y análisis inferenciales de sus patrones de resistencia fenotípica al hierro, manganeso y zinc en diferentes tiempos de exposición, concentraciones e interacciones. El análisis físico-químico del agua reveló parámetros aceptables, excepto para el pH del quinto lugar de recolección. En este sitio, se aisló a C. violaceum. Ambas cepas de C. violaceum fueron resistentes a los metales probados en diferentes brechas de exposición, concentraciones e interacciones ( $\mathrm{p}$ $<10-5)$. Sin embargo, se observó que la cepa salvaje mostró una respuesta de fase aguda más eficiente cuando se comparó con la estándar, sobre todo para las concentraciones entre 80-48 (10-1 g/l). El zinc al interactuar individualmente o en conjunto con el hierro y el manganeso elevó los patrones de resistencia en la cepa salvaje, mientras que el proceso inverso fue verificado para la cepa ATCC 12472. Las pruebas de bioprospección demostraron la importancia de la C. violaceum como herramienta para la biorremediación de metales y destacan la importancia del monitoreo ambiental y aplicación de la biorremediación en áreas afectadas por la problemática expuesta.

Palabras Clave: bioprospección, Chromobacterium violaceum, metales y resistencia bacteriana.

\section{INTRODUCTION}

The low quality of aquatic ecosystems is an important grievance faced by contemporary societies and become a concern to human health, especially because of the possibility of the spread of disease in these environments. In semi-arid, the problem of low water quality is shown even more worrying, since in this region the constant shortage of water makes it a limited good and a valuable source of local economic development (Silva and Araújo 2003).

Several studies show that many water reservoirs located in semiarid are eutrophic, with high levels of contamination and pollution, which is largely associated with the anthropic action. Among these contaminants and pollutants, metals have generated a great concern, because they are persistent, non-degradable, teratogenic, mutagenic and carcinogenic (Sousa et al. 2008). Certain concentrations of metals have toxic effects on ecosystems, interfering with natural biological processes. Most metals are lethal at high concentration; nevertheless they can be deleterious even at very low concentration causing long term negative health effects. The symptoms of intoxication by metals depend upon the particular metal, but they are largely associated with kidney, brain and gastrointestinal problems (Bruins et al. 2000).

However, despite the relevance of this issue and the necessity to propose technological decontaminant measures, in Brazil the use of environmental decontamination technologies is emergent. In this context, it is necessary the development and application of techniques aimed to reduce the pathogenic potential of contamination of ecosystems, and among these techniques it is bioremediation (Weber 2004; Singh et al. 2010). Bioremediation is defined as a process in which plants or microorganisms are used to reduce environmental pollutants or degrade toxically dangerous substances in the environment. And among the potentially important microorganisms for 
the development of this activity is Chromobacterium violaceum (Alencar et al., 2016; Kothari et al. 2017; Martins et al. 2003; Carepo 2004). C. violaceum has a wide variety of adaptive mechanisms to environmental variations; genes associated with protection against oxidative stress, as well as genes with biotechnological functions directed to reduction and/or elimination of environmental pollutants, such as metals (Alencar et al., 2017; Lima-Bittencourt et al. 2007).

Finally, with respect to low water quality in the Brazilian semiarid; the deficit in application of bioremediation methodologies; and the genetic diversity of C. violaceum this study aims to assess the water quality of a water reservoir, located in semiarid of Rio Grande do Norte (Brazil, RN) and near a mining iron industry. Furthermore, bioprospecting $C$. violaceum as a tool for metal bioremediation, through the evaluation and comparison of their phenotypic behavior of resistance to metals: iron, zinc and manganese, correlating the growth patterns this bacteria in different phases of response, concentrations and metallic interactions.

\section{Methodology}

\section{Sample collection and physical-chemical analysis of water}

It was selected five sites on Engenheiro Armando Ribeiro Gonçalves reservoir (located in the county of Jucurutu - semiarid of the RN - Brazil), where the iron mining is shown as a possible source of anthropic water contamination and pollution (MME 2005; IBGE 2010). The collection sites were described as follows: 1) Margin - near to effluent discharge; 2) Entrance of water flow - downstream discharge; 3) Margin - near to the mining industry; 4) Water flow - upstream the reservoir and 5) Downstream mining industry - proximity to Jucurutu municipality.

Samples of water in the reservoir were collected in September 2014 and March 2015, considering the dry and rainy seasons, respectively. For each collected site, the samples for the isolation and bacterial identification were collected in the water sub-surface to a depth of $20 \mathrm{~cm}$, volume of $1000 \mathrm{ml}$ and processed according to the methodology recommended by the National Water Agency (ANA, 2011). The analysis of physical and chemical parameters (temperature; dissolved oxygen density; hydrogen potential; electrical conductivity; ions chloride and water turbidity) were conducted through a multiparameter probe (Aquaread AP 7000®) and it were based on the recommendations of the Brazilian Environmental Council, following as reference the parameters established by Resolution CONAMA 430, 2011 (Brazil, 2011), for fresh waters class II, designed to supply human consumption after conventional treatment.

\section{Sampling}

Isolation and microbiological identification were performed according to the methodology recommended by the Standard Methods for Examinations of Water and Wastewater (APHA, AWWA 2012). The samples were filtered through a porous membrane of cellulose ester $47 \mathrm{~mm}$ diameter with $0.45 \mu \mathrm{M}$ mesh. After filtration, the membrane was dipped in TSB medium (Triptone Soya Broth - HIMEDIA $\Re$ ) and incubated at $35 \pm 2{ }^{\circ} \mathrm{C}$ for 24 hours. Then, after bacterial growth, there was a sample replating on nutrient agar and a new incubation at $35 \pm 2$ ${ }^{\circ} \mathrm{C}$ for 24 hours. Following this period, the colonies with aspect indicative of $C$. violaceum, such as purple or violet color were subcultured in nutrient agar and incubated again at $35 \pm 2{ }^{\circ} \mathrm{C}$ for 24 hours; the same process was carried out to the colonies isolated whose appearance was not indicative of $C$. violaceum. Finally, all bacterial isolates were submitted to identification by the automated system VITEKII (Biomerieux®). 
Evaluation of the C. violaceum resistance to metals (full factorial design $2^{3}$ )

It were used two strains of C. violaceum, one considered wild, isolated from the Engineer Armando Ribeiro Gonçalves reservoir, and other considered standard (ATCC 12472). The evaluation of the C. violaceum resistance to metals was carried out in concentrations of $\mathrm{FeSO}_{4} ; \mathrm{ZnSO}_{4}$ and $\mathrm{MgSO}_{4}$ by a full factorial design $2^{3}$, followed by measurement of absorbance and comparison of resistance patterns (Sumita et al. 2007, adapted). For data analysis, it established a comparison between the wild and ATCC C. violaceum strains, cultivated in decreasing concentrations of metal salts 48, 32, 16, 8, 4, 2 and $1\left(10^{-1} \mathrm{~g} / \mathrm{l}\right)$ for intervals of 24,48 and 72 hours. C. violaceum strains, wild and ATCC, were reactivated in nutrient broth for 24 hours at $37 \pm 2{ }^{\circ} \mathrm{C}$ in aerobic atmosphere, then subcultured on blood agar for cell screening, synchronizing, and further incubated for 24 hours at $37 \pm 2{ }^{\circ} \mathrm{C}$ in aerobic condition. From the observed microbial growth after bacterial activation, a cell suspension was prepared in saline with turbidity equivalent to MacFarland scale of 0.5. The cell suspension whose count shows expected colonies intervals (30 to 300) was diluted to $10^{-2}$ in nutrient broth and inoculated into well cell culture plates in 0.1 $\mathrm{ml}$ volumes, except for the control, which was placed only the liquid culture medium $(0.1 \mathrm{ml})$.

Then eight test tubes were numbered and to each one, it was added $0.25 \mathrm{ml}$ of concentrated solution of respective metal salts, at different concentrations. This volume was completed to $1 \mathrm{ml}$ with sterile distilled water. Afterward was added $1 \mathrm{~mL}$ of nutrient broth, prepared in double strength, in all tubes, achieving volumes with eight different combinations of metal salts. Subsequently, for each cell culture plate well it was distributed $0.1 \mathrm{~mL}$ of the experiments in order to obtain duplicates of each condition and eight controls readings. The nutrient broth containing the inoculum was added to all experiments $(0.1 \mathrm{~mL})$ and the same volume of sterile broth was added to control, completing the volume of $0.2 \mathrm{ml}$ in each well. Subsequently, the plates were incubated at intervals of 24 , 48 and 72 hours at $37 \pm 2{ }^{\circ} \mathrm{C}$ in aerobic condition. Finally it was performed the reading absorbance at $410 \mathrm{~nm}$ of each well in a microplate reader Versamax (Molecular Devices).

\section{C.violaceum Bioprospective ability to metabolize metals}

The solutions of each metal salt were used to prepare concentrations equivalent to $16 \times 10^{-1} \mathrm{~g} / 1$. Isolates of C. violaceum (wild and ATCC 12472) were bioprospecting to degradation of metals. They were inoculated in nutrient broth containing the respective metal salts, at concentrations described. Pure colonies of C. violaceum were inoculated in Erlenmeyer flasks pretreated with hydrochloric acid solution - $0.04 \mathrm{M} \mathrm{HCl}$, containing $30 \mathrm{ml}$ of nutrient broth added at respective concentrations of the aforementioned salts and incubated for 24 hours at 150 $\mathrm{rpm}$ and $37 \pm 2{ }^{\circ} \mathrm{C}$. Afterward the inoculum was standardized in $0.5 \mathrm{MacFarland}$ scale. After incubation for 24 hours at $150 \mathrm{rpm}$ and $37 \pm 2{ }^{\circ} \mathrm{C}$ it was determined the respective final concentrations of the metal salts by Atomic Absorption Spectrometry (AAS).

\section{Statistical analysis}

The statistical analysis was performed with the program R Core Team (2013). In addition to descriptive statistics was determined through the inferential of variance (ANOVA) and Tukey tests, considering a significance level of $\alpha=0.05 .^{12}$ 


\section{RESUlts AND DISCUSSION}

The environmental impacts from pollutants and/or contaminants accumulation in aquatic environments cause disorders that often hinder recovery and control of these locations. In this sense, the evaluation of the parameters indicative of changes in water quality, such as physical-chemical and microbiological, become a critical tool in the direction of efficient conducts aimed at the decontamination of these environments (Gaylarde et al. 2005).

In this study, physical, chemical and microbiological parameters were evaluated. It was observed that the temperature values of water from the observed sites showed similarities for the dry and rainy periods, except for the fifth site, which showed an average of temperature above the others for the same periods. It is noted that the data followed characteristic values for semiarid region (Silva and Araújo 2003). When assessing water salinity of the water analyzed, related to the chloride ion concentrations, it was found that the averages were 113 for the dry season and 40 for the rainy period. The chloride ion as $\mathrm{Cl}^{-}$is a major constituent of the anionic water and wastewater. In fresh water, the presence of chloride occurs naturally or can be caused by pollution; the influxed seawater; domestic sewage or industrial waste (Santos 2010).

Another parameter evaluated was the dissolved oxygen concentration in the water which presented values recommended by the law, above $10 \%$. When it was compared the two periods, it was observed a relationship between increase in temperature and decrease in oxygen concentration. The amount of dissolved oxygen in the water is a major indicator of the quality of aquatic ecosystems. If oxygen concentration is lower, organisms with mobility will leave the environment, wherever possible, while sessile animals come into stress and eventually die. In turn the $\mathrm{pH}$ of the water did not showed significant changes among the 1,2,3 and 4 sites, which presented alkaline characteristics. However, the fifth site for both dry and rainy periods shows acid characteristics. The slightly acidic values in the fifth site points out the possibility of pollution originated from mining industries or anthropogenic residues (Santos 2010).

However, despite the physical and chemical analyzes carried out on the Engenheiro Armando Ribeiro Gonçalves reservoir indicate recommended values by law. The assessment of water quality should be based not only to the physical and chemical characteristics of the environment, but also in the ecological characteristics (Bennion et al. 2005; Sousa, et al. 2008). In this sense, the present study also evaluated the biological characteristics of the water reservoir. The analysis revealed the presence of microorganisms associated with pathogenic characteristics, Table 1.

Table 1. Physical-chemical and microbiological analyzes (dry and rainy periods). T- temperature $\left({ }^{\circ} \mathrm{C}\right)$; DODissolved oxygen density (\%); pH-Hydrogen potential; ORP-Electrical conductivity (mV); Cl-Ions chloride (mg/L); NTU-Water Turbidity and Depth (m).

\begin{tabular}{|c|c|c|c|c|c|c|c|c|}
\hline \multirow[b]{3}{*}{ Site } & \multicolumn{7}{|c|}{ Water physical-chemical analysis } & \multirow[t]{2}{*}{ Water microbiological analysis } \\
\hline & \multicolumn{7}{|c|}{ Parameters assessed } & \\
\hline & $\mathbf{T}$ & DO & $\mathrm{pH}$ & ORP & $\mathrm{Cl}^{-}$ & NTU & Depth & Bacterial isolates \\
\hline \multicolumn{9}{|c|}{ Dry period } \\
\hline 1 & 31.4 & 85.8 & 8.6 & 69 & 166.4 & 22.5 & 4.1 & Enterobacter cloacae complex; Aeromonas sobria \\
\hline 2 & 33.6 & 37.9 & 8.6 & 99 & 114 & 33.9 & 1.1 & Plesiomonas shingelloides; Enterobacter aerogenes \\
\hline 3 & 34.1 & 25.5 & 7.9 & 95.7 & 113.2 & 1.9 & 1.2 & P. shingelloides; Escherichia coli \\
\hline 4 & 31.7 & 21.1 & 8.1 & 100 & 113.5 & 1.9 & 4.2 & A. sobria; $P$. shingelloides \\
\hline 5 & 36.2 & 20.7 & 6.1 & 67.7 & 108.7 & 1.9 & 1.0 & E. cloacae complex; E. coli \\
\hline \multicolumn{9}{|c|}{ Rainy period } \\
\hline 1 & 29.5 & 99 & 8.58 & 36.9 & 46.59 & 17.3 & 1.1 & E. cloacae complex \\
\hline 2 & 28.1 & 88 & 7.42 & 42.4 & 31.43 & 1.9 & 6.3 & E.cloacae complex; A.sobria \\
\hline 3 & 28.2 & 39 & 8.02 & 43.7 & 41.21 & 1.9 & 11.1 & P. shingelloides; E.aerogenes \\
\hline 4 & 27.9 & 23.2 & 7.22 & 50.3 & 42.55 & 1.9 & 7.2 & A. sobria; P. shingelloides; E. coli \\
\hline 5 & 35.7 & 23.4 & 5.90 & 48.5 & 40.07 & 1.9 & 1.5 & E. cloacae complex Morganella morganii morganii; Chromobacterium violaceum \\
\hline
\end{tabular}


In the rainy period, in addition to the organisms listed in Table 1, it is also identified C. violaceum. This bacteria is classified as a beta-proteobacteria, gram-negative, saprophytic, facultative aerobic, rod-shaped, provided with motile. It presents a creamy appearance, colonies of violet color, generally associated with the synthesis of violacein pigment (Dias et al. 2005). This microorganism is distinguished by metabolic and adaptive versatility, showing expression of genes involved in resistance to iron, zinc, copper, arsenic and cyanide; genes reducing halogen compounds to less toxic forms, as well as genes that may be used in the reduction of impacts caused by metals in the environment (Carepo et al. 2004; Azevedo et al. 2008; Castro et al. 2015).

Studies by Sumita and collaborators (2007) found high adaptive capacity of C. violaceum front of metal salts: aluminum sulfate, copper sulfate, manganese sulfate and zinc sulfate, indicating the resistance of this organism in the presence of the respective metals. In addition, numerous genes with biotechnological action are associated with this bacteria. The ability of this organism in solubilize gold, for example, by a mercury-free process has great value for gold mining (Smith et al. 1985). C. violaceum resistance to arsenic was also observed (Azevedo et al. 2008), as well to cyanide resistance mechanisms (Carepo et al. 2004) and to iron (Lima et al. 2014). The metabolic behavior of $C$. violaceum is shown as an effective and low cost alternative in areas impacted by metals, such as the study area evaluated in this research, especially in aquatic environments (Javis 2000).

In aquatic environments high concentrations of metals can often cause risks to human health and local fauna and flora. The introduction of potentially toxic elements in these environments has been one of the main problems faced by environmental agencies and researchers. In consequence several studies and decontamination tools have been proposed in recent decades. Among the techniques that have shown promising results is bioremediation, in special the application of microorganisms, such as $C$. violaceum, capable of removing metals in the environment through active and passive processes, which biodegrade or accumulate these elements in their cellular compartments (Sheng et al. 2012; Hofer et al. 2013).Thus, based on the genetic apparatus of C. violaceum in front of metals. This study conducted a series of bioprospective analyzes directed to bioremediation of metals (iron, zinc and, manganese - commonly used in the study area evaluated) by ATCC 12472 and wild strains of C. violaceum (isolated from Engenheiro Armando Ribeiro Gonçalves reservoir).

It was tested the $C$. violaceum strain isolated from the environment, with the strain ATCC 12472, not exposed to stressors. The analysis between metal concentration and bacterial growth showed that both $C$. violaceum strains presented inversely proportional patterns of growth, verified when it was analyzed the metal concentration and the absorbance rate. During the acute ( 24 hours) and chronic phases ( 72 hours) of bacterial response, it was observed that both strains showed similar patterns of resistance when exposed to low concentrations of the tested metals, 1,2 and $4\left(10^{-1} \mathrm{~g} / \mathrm{l}\right)$. However, C. violaceum wild strain, after 24 hours of incubation showed a pattern of resistance to metals, $\mathrm{FeSO}_{4} ; \mathrm{ZnSO}_{4}$ and $\mathrm{MgSO}_{4}$ and their interactions more efficient than the ATCC strain, especially at concentrations between $8-48\left(10^{-1} \mathrm{~g} / \mathrm{l}\right)$, showing thereby an efficient acute phase response to high concentrations of metals.

The concentrations of metals, used in this study, are above the values established by national legislation, resolution CONAMA 430/2011 (Brasil, 2011), regarding the quality of water for drinking and human consumption, as well as those referred by CONAMA resolution 420/2009 (Brasil 2009), parameters for prevention and intervention in soil and groundwater impacted by metals. Even with the high metal concentrations of experiments, it was observed a pattern of resistance for both $C$. violaceum strains. Such metabolic characteristics demonstrated in this study show the versatility and the adaptability of $C$. violaceum front of the metals tested.

This fact can be explained by the existence of numerous mechanisms of bacterial resistance to metals. The surface of the bacteria is analogous to the surface of the mineral, with regard to the existence of functional groups which attract cationic species such as metals; in general bacterial cells do not differentiate physiologically those considered toxic metals during the assimilation process. At high concentrations, metal ions are transported across the cell membrane by a chemo-osmotic process from carrier proteins that act in the inorganic metal transport system or by non-specific intracellular transport processes. While in conditions of low metal concentration occurs 
the action of a co-transport system, expressed in metallic limiting conditions and activated by ATP and/or proton motive force. Furthermore, it is believed that hydrophilic metal ions are transported across the hydrophobic space of the bacterial membrane by facilitated diffusion mechanisms through the cell membrane while in hydrophobic situations it tends to occur by direct diffusion of metal ions to the bacterial cytoplasm (Velasquez and Dussan 2009; Vargas-García et al. 2012; Alencar et al. 2017).

Inferential analyzes for time, concentrations and metallic interactions comparison revealed that the exposure time between the acute-chronic and the acute-intermediate stage (48 hours) significantly influenced the patterns of resistance to metals for both strains (wild and ATCC 12472). Furthermore, the lower metal concentrations, ranging between $1-2\left(10^{-1} \mathrm{~g} / \mathrm{l}\right)$ showed statistical significance on the wild and ATCC strains growth patterns, when compared with concentrations considerably higher, $8-480\left(10^{-1} \mathrm{~g} / \mathrm{l}\right)$, with the exception to relations $4-8$ and $4-16\left(10^{-1} \mathrm{~g} / \mathrm{l}\right)$.

Analysis of the influence of metal interactions on resistance patterns in both $C$. violaceum strains revealed that the iron element differs significantly from the other individual elements $\left(\mathrm{ZnSO}_{4}\right.$ and $\left.\mathrm{MgSO}_{4}\right)$, and the interactions with each other $\left(\mathrm{FeSO}_{4}-\mathrm{ZnSO}_{4}\right) ;\left(\mathrm{FeSO}_{4}-\mathrm{ZnSO}_{4}-\mathrm{MgSO}_{4}\right)$ and $\left(\mathrm{ZnSO}_{4}-\mathrm{MgSO}_{4}\right)$, except for $\left(\mathrm{FeSO}_{4}-\mathrm{MgSO}_{4} / \mathrm{FeSO}_{4}\right)$ interaction. Whereas zinc element differs significantly only for the relationship between $\left(\mathrm{ZnSO}_{4} / \mathrm{FeSO}_{4}-\mathrm{MgSO}_{4}\right.$; $\left(\mathrm{ZnSO}_{4} / \mathrm{FeSO}_{4}-\mathrm{ZnSO}_{4}\right)$ and $\left(\mathrm{ZnSO}_{4} / \mathrm{MgSO}_{4}\right)$, while the manganese element differs for the relationship between $\left(\mathrm{MgSO}_{4} / \mathrm{FeSO}_{4}-\mathrm{ZnSO}_{4}\right)$ and $\left(\mathrm{ZnSO}_{4}-\mathrm{MgSO}_{4} / \mathrm{MgSO}_{4}\right)$. Moreover, it was observed a statistical significance between the two C. violaceum strains, showing an higher resistance to metals of the wild type strain in relation to the ATCC 12472. The same degree of significance was found regarding both strains, wild and ATCC 12472, in relation to the zero/control (only metal and absence of bacterial growth). When it was established a comparison between the ratio of metal bioremediated and the metal resistance of $C$. violaceum, there was observed a statistical significance between $\left(\mathrm{MgSO}_{4}-\mathrm{FeSO}_{4}\right) ;\left(\mathrm{ZnSO}_{4}-\mathrm{FeSO}_{4}\right)$ and $\left(\mathrm{ZnSO}_{4}-\mathrm{MgSO}_{4}\right)$ association, Table 2.

Concerning metal interactions observed, it was found that the zinc, when interacted with $\mathrm{FeSO}_{4}$ and $\mathrm{MgSO}_{4}$ alone or $\mathrm{FeSO}_{4}$ and $\mathrm{MgSO}_{4}$ together, increased the resistance pattern of $C$. violaceum wild strain. This characteristic suggests a possible interaction between mentioned elements and proposes a model for treatment of affected environments by $\mathrm{ZnSO}_{4}$, wherein the bacterial resistance, coupled with its capacity to bioremediation can be enhanced by adding $\mathrm{FeSO}_{4}$ and/or $\mathrm{MgSO}_{4}$. Furthermore, the resistance mechanisms developed by the wild strain on metals iron and manganese propose the use of this bacteria as a tool for bioremediation in the area where it was isolated, since the isolation of the respective strain occurred in a water reservoir impacted by iron mining industry and it is known that manganese is commonly used in the processing of iron, Table 2 .

Table 2. Comparative inferential analyzes of metabolic efficiency of two strains of $C$. violaceum and metal bioremediated. * significance level: +++ high significance. ${ }^{\text {a }}$ The table only describes the metallic form of salt in the respective interactions tested.

\begin{tabular}{|c|c|c|c|c|c|}
\hline \multicolumn{2}{|c|}{ Concentration $\left(10^{-1} \mathrm{~g} / 1\right)$} & \multicolumn{2}{|c|}{ Metal interaction } & \multicolumn{2}{|c|}{ Time (hours) } \\
\hline Comparison & P value & Comparison $^{\mathrm{a}}$ & $P$ value & Comparison & P value \\
\hline $48-24$ & 0.55 & $\mathrm{Fe}-\mathrm{Mg} / \mathrm{Fe}$ & 0.5 & $48-24$ & $<10^{-5}$ \\
\hline $40-10$ & $<10^{-2}$ & $\mathrm{Fe}-\mathrm{Zn} / \mathrm{Fe}$ & $<10^{-5}$ & $72-24$ & $<10^{-5}$ \\
\hline $80-10$ & $<10^{-5}$ & $\mathrm{Fe}-\mathrm{Zn}-\mathrm{Mg} / \mathrm{Fe}$ & $<10^{-5}$ & $72-48$ & 0.39 \\
\hline $160-10$ & $<10^{-5}$ & $\mathrm{Mg} / \mathrm{Fe}$ & $<10^{-2}$ & & \\
\hline $320-10$ & $<10^{-5}$ & $\mathrm{Zn} / \mathrm{Fe}$ & $<10^{-5}$ & Strain & Significance $^{1}$ \\
\hline $480-10$ & $<10^{-5}$ & $\mathrm{Zn}-\mathrm{Mg} / \mathrm{Fe}$ & $<10^{-5}$ & Wild-ATCC & \\
\hline $40-20$ & 0.42 & $\mathrm{Fe}-\mathrm{Zn} / \mathrm{Fe}-\mathrm{Mg}$ & $<10^{-5}$ & Zero-ATCC & $+++^{2}$ \\
\hline $80-20$ & 0.04 & $\mathrm{Fe}-\mathrm{Zn}-\mathrm{Mg} / \mathrm{Fe}-\mathrm{Mg}$ & $<10^{-5}$ & Zero-Wild & \\
\hline $20-160$ & $<10^{-4}$ & $\mathrm{Mg} / \mathrm{Fe}-\mathrm{Mg}$ & 0.73 & Metal & \\
\hline $320-20$ & $<10^{-5}$ & $\mathrm{Zn} / \mathrm{Fe}-\mathrm{Mg}$ & $<10^{-5}$ & $\mathrm{Mn}-\mathrm{Fe}$ & \\
\hline $480-20$ & $<10^{-5}$ & $\mathrm{Zn}-\mathrm{Mg} / \mathrm{Fe}-\mathrm{Mg}$ & $<10^{-5}$ & $\mathrm{Zn}-\mathrm{Fe}$ & $+++^{2}$ \\
\hline $80-40$ & 0.97 & $\mathrm{Fe}-\mathrm{Zn}-\mathrm{Mg} / \mathrm{Fe}-\mathrm{Zn}$ & 0.36 & $\mathrm{Zn}-\mathrm{Mn}$ & \\
\hline
\end{tabular}




\begin{tabular}{cccc}
$40-160$ & 0.12 & $\mathrm{Mg} / \mathrm{Fe}-\mathrm{Zn}$ & $<10^{-3}$ \\
$40-320$ & $<10^{-3}$ & $\mathrm{Zn} / \mathrm{Fe}-\mathrm{Zn}$ & 0.02 \\
$480-40$ & $<10^{-5}$ & $\mathrm{Zn}-\mathrm{Mg} / \mathrm{Fe}-\mathrm{Zn}$ & $<10^{-3}$ \\
$80-160$ & 0.68 & $\mathrm{Mg} / \mathrm{Fe}-\mathrm{Zn}-\mathrm{Mg}$ & $<10^{-5}$ \\
$80-320$ & 0.01 & $\mathrm{Zn} / \mathrm{Fe}-\mathrm{Zn}-\mathrm{Mg}$ & 0.95 \\
$80-480$ & $<10^{-5}$ & $\mathrm{Zn}-\mathrm{Mg} / \mathrm{Fe}-\mathrm{Zn}-\mathrm{Mg}$ & 0.26 \\
$320-160$ & 0.69 & $\mathrm{Zn} / \mathrm{Mg}$ & $<10^{-5}$ \\
$480-160$ & $<10^{-2}$ & $\mathrm{Zn}-\mathrm{Mg} / \mathrm{Mg}$ & $<10^{-5}$ \\
$480-320$ & 0.43 & $\mathrm{Zn}-\mathrm{Mg} / \mathrm{Zn}$ & 0.91 \\
\hline
\end{tabular}

${ }^{1}$ Tukey test:

Comparative and inferential analyzes to reduce the in vitro concentration of metals by $C$. violaceum and the influence of the metallic interactions in this process.

${ }^{2}$ Significance level:

+++ High significance

Comparing only the influence of time on the growth patterns of the two strains, exposed to the referenced metal concentrations, there was a trend of stabilization of resistance patterns with exposure time, being observed a decline in the acute response in wild strain between the ranges of 48 to 72 hours compared to the ATCC strain. When analyzing the bacterial resistance ratio and the metal interactions it was observed that $\mathrm{ZnSO}_{4}$ was considered the metal, which more interfered in C. violaceum resistance patterns, followed by $\mathrm{MgSO}_{4}$ and $\mathrm{FeSO}_{4}$. However, it was found that the $\mathrm{ZnSO}_{4}$ when interacting with $\mathrm{FeSO}_{4}$ and $\mathrm{MgSO}_{4}$ individually; or with $\mathrm{FeSO}_{4}$ and $\mathrm{MgSO}_{4}$ together tended to increase the resistance patterns in C. violaceum wild strain, unlike in ATCC 12472 strain, in which the same interactions potentiate the effect of zinc toxicity, reducing the resistance pattern of this strain. Despite the remarkable resilience to the metals tested in $C$. violaceum wild strains, isolated from environments impacted by human action compared to ATCC 12472, especially in the acute phase response, it was observed an improved efficiency in ATTC 12472 resistance patterns to the metal iron in the chronic phase response (48 and 72 hours) when compared to the wild strain (Table 2 and Figure 1). 
Figure 1. Growth pattern in $C$. violaceum strains (wild and ATCC 12472), according to the time of exposure, concentration and interaction between iron, manganese and zinc. SD - Standard Deviation. The table only describes the metallic form of salt in the respective interactions tested.

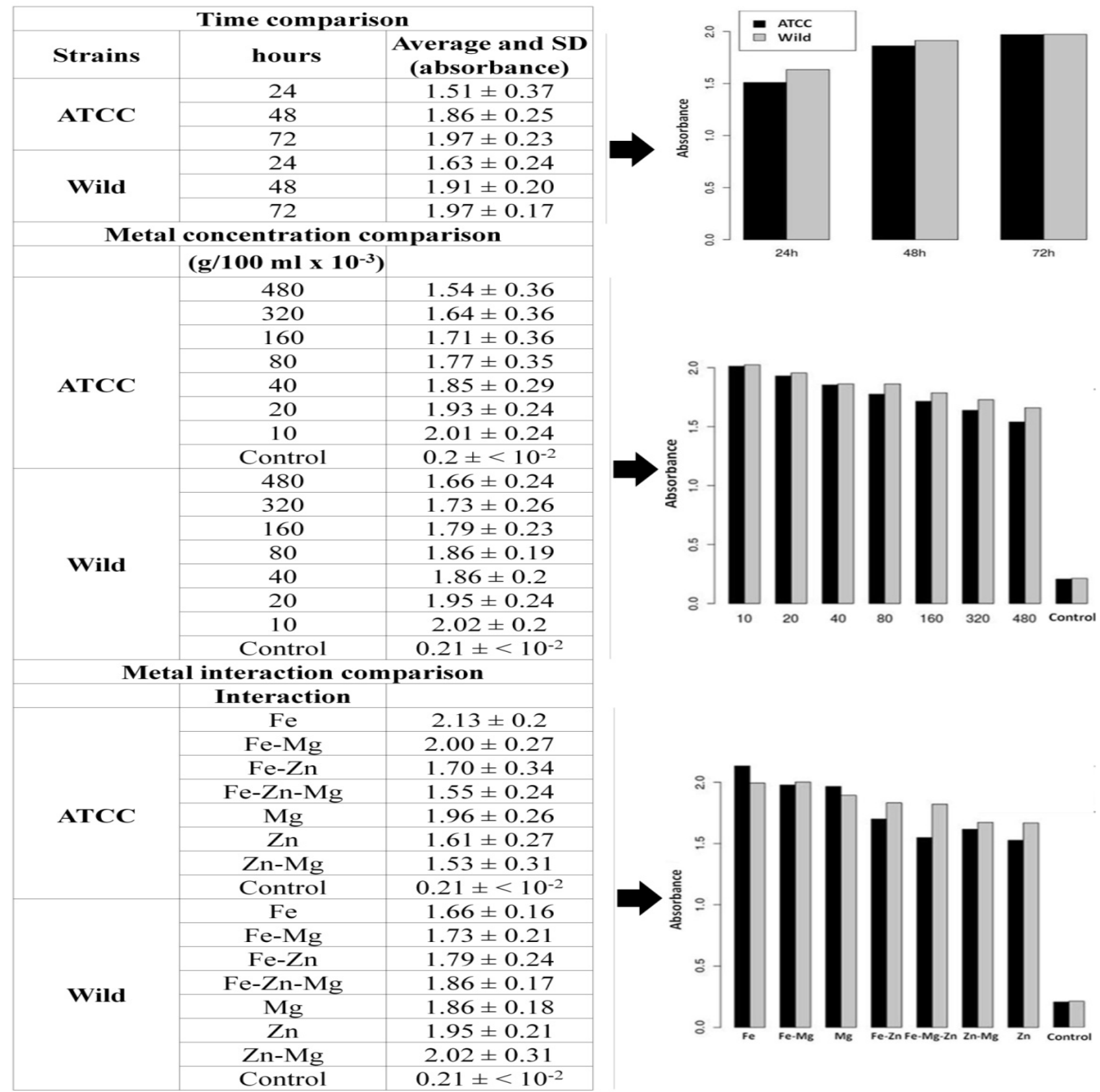

Aiming to test the hypothesis which states that bacteria exposed to environments impacted by pollution, as resulting from the action of metals, present more efficient resistance mechanisms when compared to those not exposed to these stressors. It was performed a bioprospecting on the resistance/growth patterns and the bacterial capacity to reduce the metallic concentration in a simulated environment impacted by metals $\left(\mathrm{FeSO}_{4}, \mathrm{MgSO}_{4}\right.$ and $\mathrm{ZnSO}_{4}$ - in vitro test). The statistical analysis showed a efficiency for both strains. However when comparing the pattern of resistance/growth of the wild, isolated from reservoir studied, and the standard strain, ATCC 12472, it was observed greater efficiency of the wild strain compared to the standard one, especially for the iron element, Figure 2. 
Figure 2. Bioprospecting analyze of $C$. violaceum activity for metal bioremediation. * Initial metal concentration in $16 \times 10^{-1} \mathrm{~g} / 1$ (control), **Standard Deviation. The table only describes the metallic form of the salt evaluated.

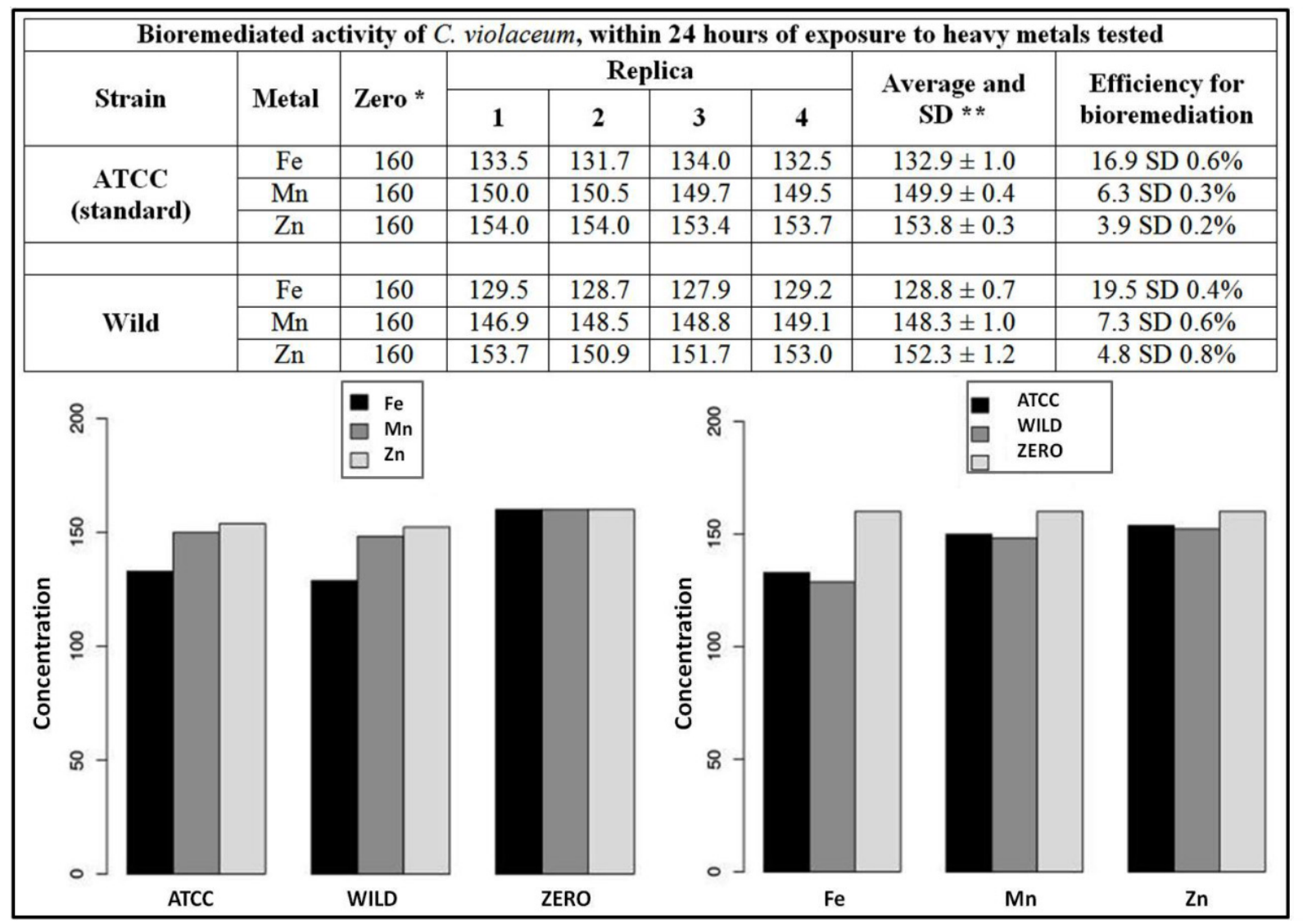

The relative metabolic efficiency observed in C. violaceum wild strain in relation to ATCC 12472 it suggests that bacteria when exposed to certain pollutants and contaminants tend to develop resistance mechanisms against the selective pressures imposed by the environment. According to Ellis and collaborators (2003), exposure of microorganisms to metals leads to the development of tolerance by the microbial community. Some bacteria, when exposed to high levels of metals, acquire resistance mechanisms which enable their survival in stressful condition (Abdelatey et al. 2011). These mechanisms encoded by chromosomal gene or plasmid loci include, efflux pumps, enzymatic detoxifying, intra and extracellular ion sequestration and reduction of contaminant to a less toxic form (Alencar et al., 2017; Castro-silva et al. 2003; Rathnayake et al. 2009).

The comparative resistance patterns among C. violaceum strains show that the wild is more efficient when compared to the ATCC 12472 suggest a possible influence of the eutrophication process, since the isolation of more resistant bacteria were performed in an environment affected by human action. In these places the ecological imbalance resulting from the excess of elements such as $\mathrm{C}, \mathrm{N}$ and $\mathrm{P}$ tend to change the nutritional intake of organisms that live there, influencing biological patterns of growth and resistance against the different contaminants and pollutants released into the environment, besides the abundance, composition, virulence and survival of existing pathogens in aquatic ecosystems (Smith and Schindler 2009). The accumulation of metals in the environment can reduce the biomass of organisms, the activity of several enzymes, the structure of microbial communities and functional diversity of less tolerant microorganisms. Therefore, the exposure of microorganisms to metals can exert selective pressure on bacteria and resistance to these elements (Ellis et al., 2003).

Based on the observed context, it is highlighted that aquatic ecosystems have been altered at different scales as a result of the various environmental impacts from anthropogenic activities, for instance the mining industry. The impacts of pollution on the environment, health and quality of life leave no doubt to the necessity of a better management of these locations. Physical-chemical and biological monitoring of the environmental water 
quality is an important tool both for the management of natural resources and for the supply of subsidies for the development of public policies. In this study, it was observed that $C$. violaceum demonstrated a potential use in areas impacted by human activities coming from the mining, such as. This work demonstrated the critical importance of C. violaceum as a bioprospecting microorganism capable of bioremediate metals, as well as the importance of action remediation alternatives methodologies to environments impacted by pollution and contamination (Alencar et al., 2016; Abou Shanab, et al., 2007, Kermani et al, 2010; Ahemad and Malik, 2012).

In this scenario, bioremediation emerges as a methodological alternative of low cost and high efficiency and bioprospecting for microorganisms that may be used in bioremediation of degraded ecosystems is the first step in research aimed at using microbial activity to solve this problem. In this study, bacterial resistance patterns observed in C. violaceum front of high metal concentrations show their metabolic versatility and the presence of protective and adaptability mechanisms. Resistance patterns analyzed proposes to carry out studies aimed to evaluating $C$. violaceum ability for bioremediation of metals and the consequent development and application of biotechnology tools in areas affected by metal pollution/contamination (Alencar et al. 2016).

\section{ConClusion}

In recent years, the major concerns about the environment and the creation of goals for the realization of an effective sustainable development in the semiarid region have aroused the interest of researchers regarding the accomplishment of numerous studies pertinent to the theme. The search for new ways to solve environmental problems has been satisfactorily carried out with the help of biotechnology. Through techniques, such as, bioremediation, it is becoming possible to recover degraded areas in a sustainable way, that is, cleanly without causing secondary damage to the environment. However, even with the new biotechnological techniques developed in the market, there are still deficiencies in their applications, often due to the inability of public management systems, coupled with lack of knowledge about them. Therefore, it is necessary to build a new model of sustainable development for the Brazilian semiarid region, based on efficient public policies that promote a true scientific and educational revolution, in order to spread biotechnology as a means of promoting environmental, social and economic development.

Much has to be done to achieve sustainable development, but it can be said that there are already positive results with some new techniques and attitudes developed, such as bacterial bioremediation, based on the use of microorganisms resistant to stressors present in the environment, such as, the relationship between C. violaceum and heavy metals. However, there is a need for improvement and greater encouragement of these new techniques. Therefore, it is necessary to build a new technical-scientific paradigm directed to the sustainable development of the semiarid region, opening new perspectives, enabling the revitalization of its economic and social potentialities, often compromised by the problematic environment linked to the lack of management in these locations.

\section{REFERENCES}

Abdelatey, LM, Khalil WKB, Ali TA., MAHROUS, K. F. Heavy metal resistance and gene expression analysis of metal resistance genes in Gram-positive and Gram- negative bacteria present in egyptian soils. Journal of Applied Sciences in Environmental Sanitation, v. 6, n. 2, p. 201-211, 2011.

Abou-Shanab RAI, Berkum P, Angle JS. 2007. Heavy metal resistance and genotypic analysis of metal resistance in Gram-positive and Gram-negative bacteria present in Ni-rich serpentine soil and in the rhizosphere of Alyssum murale. Chemosphere, 68:360-367. 
Agência Nacional de Água. Ministério do Meio Ambiente (ANA). 2011. Guia nacional de coleta e preservação de amostras - água, sedimentos, comunidade aquáticas e efluentes líquidos. CETESB.

Ahemad M, Malik A. 2012. Bioaccumulation of heavy metals by zinc resistant bacteria isolated from agricultural soils irrigated with wastewater. Bacteriology Journal, 2(1):12-21.

Alencar FLS, Do Nascimento ED, Araújo MFF. Microbiology for environmental conservation: a systematic review of bioremediation of heavy metals by Chromobacterium violaceum. Gaia Scientia, 10(4):408-423, 2016.

Alencar FLS, Navoni JÁ, Amaral VS. 2017. The use of bacterial bioremediation of metals in aquatic environments in the twenty-first century: a systematic review. Environmental science and pollution research, 25:1-15.

American Public Health Association (APHA); American Water Works Association (AWWA); Water Environmental Federation (WEF). 2012. Standard Methods for the Examination of Water and Wastewater, 21 ed. Washington.

Azevedo JS, Silva-Rocha R, Silva A, Carepo MSP, Schneider MPC. 2008. Gene expression of the arsenic resistance operon in Chromobacterium violaceum ATCC 12472. Canadian Journal of Microbiology, 54(42): 137.

Bennion $\mathrm{H}$ et al. 2005. The use of a GIS-based inventory to provide a national assessment of standing waters at risk from eutrophication in Great Britain. Science and the Tota Environment, 344:259-273.

Brasil. Resolução CONAMA 430, de 13 de maio de 2011. Dispõe sobre as condições e padrões de lançamento de efluentes, complementa e altera a Resolução no 357, de 17 de março de 2005, do Conselho Nacional do Meio Ambiente-CONAMA. Diário Oficial da União, Brasília, DF, n. 92, 16 de maio de 2011, page 89 .

Resolução CONAMA 420, de 28 de dezembro de 2009. Dispõe sobre critérios e valores orientadores de qualidade do solo quanto à presença de substâncias químicas e estabelece diretrizes para o gerenciamento ambiental de áreas contaminadas por essas substâncias em decorrência de atividades antrópicas. Diário Oficial da União, Brasília, DF, n. 249, 30 de dezembro de 2009, p. 81-84.

Bruins M, Kapil SE, Oehme F. 2000. Microbial resistance to metal in the environment. Ecotoxicology and Environmental Safety, 45:198-207.

Carepo MSP. et al. 2004. Identification of Chromobacterium violaceum genes with potential biotechnological application in environmental detoxification. Genetics and Molecular Research, 3(1):181-194.

Castro D et al. Proteomic analysis of Chromobacterium violaceum and its adaptability to stress. BMC Microbiol, 15, 2015.

Castro-Silva MA, Lima AOS, Gerchenski AV et al. 2003. Heavy metal resistance of microorganisms isolated from coal mining environments of Santa Catarina. Brazilian Journal of Microbiology, 34:7-45.

Dias JP et al. 2005. Chromobacteriosis in Ilhéus, Bahia: epidemiologic, clinical and laboratorial investigation. Revista da Sociedade Brasileira de Medicina Tropical, 38(6):503-506.

Ellis RJ, Morgan P, Weightman AJ, Fry JC. 2003. Cultivation dependant and independent approache for determining bacterial diversity in heavy-metal contaminated soil. Applied Environmental Microbiology, 69:3223-3230.

Gaylarde CC, Belinaso ML, Manfio GP. 2005. Aspectos biologicos e técnicos da biorremediaçao de xenobióticos. Biotecnologia ciência e desenvolvimento, 34:36 - 43 . 
Hofer C, Borer F, Bono R, Kayser A, Papritz A. 2013. Predicting topsoil heavy metal content of parcels of land: An empirical validation of customary and constrained lognormal block kriging and conditional simulations. Geoderma, 193-194:200-212.

Instituto Brasileiro de Geografia e Estatistica (IBGE). Censo Demografico do múnicipio de Jucurutu, 2010. Available at: http://cidades.ibge.gov.br/xtras/perfil.php?lang=\&codmun=240610. Acessed in: February 2015.

Javis AP, Younger PL. 2000. EIA procedure: Broadening the scope of mine water environmental impact assessment: a UK perspective. Environmental Impact Assessment Review, 85-96.

Kermani AJN et al. 2010. Cadmium bioremediation by metal-resistant mutated bacteria isolated from active sludge of industrial effluent. Iranian Journal of Environmental Health Science and Engineering, 10(4):279-286.

Kothari V, Sharma S, Padia D. Recent research advances on Chromobacterium violaceum. Asian Pacific Journal of Tropical Medicine, 10(8):744-752, 2017

Lima DC, Duarte FT, Medeiros VKS et al. 2014. The influence of iron on the proteomic profile of Chromobacterium violaceum. BMC Microbiology, 14:267.

Lima-Bittencourt CI et al. 2007. Analysis of Chromobacterium sp. natural isolates from different Brazilian ecosystems. BMC microbiology, 7:58.

Martins ALC, Bataglia OC, Camargo OA. 2003. Copper, nickel and zinc phytoavailability in an oxisol amended with sewage sludge and liming. Scientia Agricola, 60(4):747-754.

Ministério de Minas e Energia - Secretaria de Geologia, Mineração e Transformação Mineral. Diagnóstico do município de Jucurutu. 2005. Projeto cadastro de fontes de abastecimento por água subterrânea - Rio Grande do Norte - RN.

R Core Team. 2013. R: A language and environment for statistical computing. R Foundation for Statistical Computing, Vienna, Austria, Available at: http://www.R-project.org/. Acessed January 2016.

Rathnayake IVN, Megharaj M, Bolan N, Naidu R. 2009. Tolerance of heavy metal by Gram positive soil bacteria. World Academy of Science, Engineering and Technology, 53:1185-1189.

Santos VO. 2010. Physico Chemical Analysis of water collected from Rio Itapetininga-SP: a comparison between two collection points. Revista Eletrônica de Biologia, 3(1):99-115.

Sheng J, Wang X, Gong P, Tian L, Yao T. 2012. Heavy metals of the Tibetan top soils: Level, source, spatial distribution, temporal variation and risk assessment. Environmental Science and Pollution Research, 19:3362-3370.

Silva RCA and Araújo TM. 2003. Groundwater quality in urban areas of Feira de Santana, State of Bahia. Ciência e Saúde Coletiva, 9(4):1019-1028.

Singh A et al. 2010. Health risk assessment of heavy metals via dietary intake of foodstuffs from the wastewater irrigated site of a dry tropical area of India. Food and Chemical Toxicology, 48:611-619.

Smith AD and Hunt RJ. 1985. Solubilisation of gold by Chromobacterium violaceum. Journal Chemistry Technology Biotechnology, 35(2):110-116. 
Smith VH and Schindler DW. 2009. Eutrophication science : where do we go from here ? Trends in Ecology and Evolution, 24:201-207.

Sousa W, Attayde JL, Rocha ES, Eskinazi-Sant'Anna EM. 2008. The response of zooplankton assemblages to variations in the water quality of four man-made lakes in semi-arid northeastern Brazil. Journal of Plankton Research, 30(6):699-708.

Sumita TC, Pereira RS, Silva MB, Rosa LCL, Ueno M. 2007. Evaluation of interaction of Zinc, Aluminum, Copper and Manganese on Chromobacterium violaceum. Ambiente \& Água - An Interdisciplinary Journal of Applied Science, 2:44-53.

Vargas-García MC, López MJ, Suárez-Estrella F, Moreno J. 2012. Compost as a source of microbial isolates for the bioremediation of heavy metals: in vitro selection. Science of the Total Environment, 431:62-67.

Velasquez L and Dussan J. 2009. Biosorption and bioaccumu- lation of heavy metals on dead and living biomass of Bacillus sphaericus. Journal of Hazardous Materials, 167:713-716.

Weber J.2004. Biogeochemical processes and role of heavy metals in the soil environment. Geoderma, 122:105-107. 